\title{
Hypoglycaemic activity of \\ 2-dodecyl-6-methoxycyclohexa-2,5-diene-1,4-dione in streptozotocin-induced diabetic mice through ameliorating metabolic function and regulating peroxisome proliferator-activated receptor $\gamma$
}

\author{
Kintoko Kintoko, Xiaohui Xu, Xing Lin, Yang Jiao, Qingwei Wen, Zhaoni Chen, Jinbin Wei, \\ Tao Liang, Renbin Huang
}

Pharmaceutical College, Guangxi Medical University, Guangxi, China

Submitted: 31 May 2016

Accepted: 12 August 2016

Arch Med Sci 2018; 14, 5: 1163-1172

DOI: https://doi.org/10.5114/aoms.2016.63285

Copyright $\odot 2016$ Termedia \& Banach

\section{Abstract}

Introduction: Diabetes mellitus is characterized by hyperglycaemia causing changes in plasma lipoproteins, which leads to insulin resistance, secretion defects or both. The present study aimed to evaluate the ability of 2-dodecyl-6-methoxy-cyclohexa-2,5-diene-1,4-dione (DMDD) isolated from Averrhoa carambola L. roots to lower hyperglycaemia and to investigate its potential mechanism in diabetic mice.

Material and methods: DMDD was isolated using a column chromatographic technique. Experimental mice were fed with a high-fat diet for a month and were intravenously injected with streptozotocin ( $80 \mathrm{mg} / \mathrm{kg}$, single dose). Diabetic mice were orally administered $\operatorname{DMDD}(12.5,25,50 \mathrm{mg} / \mathrm{kg})$ and $50 \mathrm{mg} / \mathrm{kg}$ pioglitazone for 15 days. Fasting blood glucose (FBG), fasting blood insulin (FINS), pancreatic insulin content, interleukin-6 (IL-6), tumour necrosis factor- $\alpha$ (TNF- $\alpha$ ), as well as serum total cholesterol (TC), triglyceride (TG) and free fatty acid (FFA) were determined. Adipose tissue was assessed by histological examination, immunohistochemistry, western blot and reverse transcription-polymerase chain reaction methods.

Results: DMDD significantly increased the insulin level (all $p<0.05$ ). In contrast, FBG, IL- 6 , TNF- $\alpha$, TC, TG and FFA were significantly decreased (all $p<0.05$ ). However, DMDD induced the activation of adipocyte peroxisome proliferator-activated receptor $\gamma$ (PPAR- $\gamma$ ), confirmed by increased protein and mRNA expression of PPAR- $\gamma$.

Conclusions: DMDD possessed hypoglycaemic activity due to its potential mechanism involving PPAR $\gamma$-mediated adipocyte endocrine regulation.

Key words: Averrhoa carambola L., diabetes, mechanism, adipocyte, endocrine, peroxisome proliferator-activated receptor $\gamma$.

\section{Introduction}

Diabetes mellitus is a group of metabolic diseases characterized by hyperglycaemia resulting from defects in insulin secretion, insulin action or both [1]. Type 2 diabetes accounts for nine in ten total diabetes diag-
Corresponding author: Prof. Renbin Huang Pharmaceutical College Guangxi Medical University No. 22, Shuangyong Road Nanning

530021 Guangxi, China Phone: +86 7715339805 E-mail: huangrenbin5818@163.com 
noses [2], whereas the incidence of type 1 diabetes is estimated to be increasing by $3 \%$ per year [3]. The research has estimated that the prevalence of diabetes has increased in recent decades, and the worldwide mortality from diabetes has increased to 1.3 million deaths in 2010 [4], whereas in China, the number of diabetic patients is forecast to increase from 20.8 million in 2000 to 42.3 million in 2030 [5].

Averrhoa carambola L. (family: Oxalidaceae), also known as the star fruit, is one of the most commonly used herbs in Chinese plant medicine for the treatment of diabetes [6]. Many studies have evaluated the hypoglycaemic activity of Averrhoa carambola L. [7-11]. It has been reported that the roots of Averrhoa carambola L. could lower hyperglycaemia in KKAy diabetic mice [12]. Several medicinal plants contain compounds that possess antidiabetic activity [13]. Natural compounds and synthetic derivatives possessing a 1,4-benzoquinone moiety are associated with a range of biological properties [14] including antidiabetic activity [15]. 2-Dodecyl-6-methoxy-cyclohexa-2,5-diene1,4-dione (DMDD) isolated from Averrhoa carambola $\mathrm{L}$. roots is a 1,4-benzoquinone derivative [16].

Hypertriglyceridaemia and hypercholesterolaemia are common characteristics of the dyslipidaemia associated with insulin resistance and type 2 diabetes mellitus [17]. Excess lipids are stored in adipose and ectopic tissue. Decreasing the number of large adipocytes through induction of apoptosis is one strategy to reduce hypertriglyceridaemia, which increases insulin sensitivity [18]. In addition, many studies have reported that lipid homeostasis is also controlled by peroxisome proliferator-activated receptor $\gamma$ (PPAR- $\gamma$ ) ligands which could regulate the endocrine function of adipocytes [19]. Increased-PPAR- $\gamma$ expression was associated with insulin sensitivity, which promotes $\beta$-cell preservation [20]. According to our previous studies, total extracts of Averrhoa carambola L. root could lower the interleukin (IL)- 6 and tumor necrosis factor (TNF)- $\alpha$ level in serum and liver tissue [21]. This may indicate that Averrhoa carambola $L$. root exerts a hypoglycaemic effect by regulating the level of adipocytokines.

Therefore, the present study aimed to evaluate hypoglycaemic activity of DMDD of Averrhoa carambola L. roots as well as to investigate its hypoglycaemic mechanism associated with adipocyte endocrine regulation.

\section{Material and methods}

\section{Plants}

The roots of Averrhoa carambola L. were collected from Lingshan County, Guangxi Province, China, and were identified by Prof. Maoxiang Lai. The plant collections were carried out on private land, and the owner of the land has confirmed and given permission for us to conduct the study on the site. The voucher specimen (no. 20100605) was deposited in the herbarium of the Guangxi Institute of Chinese Medicine and Pharmaceutical Science, Guangxi, China.

\section{Chemicals}

Ethanol (EtOH), cyclohexane, ethyl acetate (EtOAc), n-butanol (n-BuOH), methanol $(\mathrm{MeOH})$, Tween 80 and STZ were purchased from Sigma (St. Louis, MO, USA). Pioglitazone was purchased from Zhongmei Huadong Pharmaceutical Co., Ltd. (Hangzhou, China).

\section{Animals}

Male Kunming mice (18-23 g) were purchased from the Laboratory Animal Centre, Guangxi Medical University, China. They were housed in a temperature-controlled room $\left(22-25^{\circ} \mathrm{C}\right)$ with a $12 \mathrm{~h}$ light-dark cycle. The animals were fed with free access to standard rodent chow served by the Laboratory Animal Centre and free access to water ad libitum. The animal protocol was approved by the institutional ethical committee of Guangxi Medical University (approval no. 20110501202), and this study was conducted in accordance with the US guidelines (NIH publication no. 85-23, revised in 1985) for laboratory animal use and care.

\section{Isolation of DMDD}

DMDD was prepared as previously described by Wen et al. [16], with a minor change. A powder from air-dried roots of Averrhoa carambola $\mathrm{L}$. $(12 \mathrm{~kg})$ was extracted with $60 \%$ aq. EtOH under reflux three times ( $3 \times 96 \mathrm{l}, 1 \mathrm{~h}$ for each). The ethanol solution was concentrated under vacuum conditions to yield a syrup-like extract, which was suspended in $\mathrm{H}_{2} \mathrm{O}$ and then extracted with cyclohexane $(3 \times 20 l)$, EtOAc $(3 \times 20 l)$ and $n-B u O H ~(3 \times 20 l)$.

The cyclohexane extract $(10.3 \mathrm{~g})$ was subjected to open silica gel CC $(3 \times 80 \mathrm{~cm}, 200-300$ mesh) via successive elution with a gradient of cyclohexane/EtOAc (100:0-0 : 100, each $200 \mathrm{ml}$ ) to yield seven fractions (fractions 1-7). Fraction 4 (5.0 g) was further separated by open silica gel CC (3 × $80 \mathrm{~cm}, 200-300$ mesh) via successive elution with a gradient of cyclohexane/EtOAc (100 : 0-15 : 1, each $100 \mathrm{ml}$ ), producing 4 sub-fractions (fractions 41-44). Fraction 44 was re-crystallized with $\mathrm{MeOH}$ to yield 2-dodecyl-6-methoxycyclohexa-2,5-diene-1,4-dione (2350 mg). This compound was identified by FTIR spectroscopy using a Spectrum One PerkinElmer spectrophotometer and by ${ }^{1} \mathrm{H}$ and ${ }^{13} \mathrm{C}$ NMR analysis on a Bruker AV 600 instrument. The chemical structure of DMDD is illustrated below (Figure 1). 


\section{Experimental design}

Type 2 diabetic mice were established by highfat diet and STZ injection. Experimental mice were fed with a high-fat diet for a month and the mice of the normal group were given standard rodent chow. Subsequently, STZ was freshly dissolved in saline-1\% Tween 80 at the dose of $80 \mathrm{mg} / \mathrm{kg}$ body weight and was immediately intravenously injected into overnight-fasted mice tail vein, whereas the normal group was only given vehicle (saline-1\% Tween 80 ). After $72 \mathrm{~h}$, mice recording fasting blood glucose levels more than $11.1 \mathrm{mM}$ were confirmed as diabetic and used in this experiment. DMDD was dissolved in saline-1\% Tween 80 solutions to obtain fixed doses of $12.5,25$ and $50 \mathrm{mg} / \mathrm{kg}$. Mice were randomly divided into six groups, each group consisting of 10 mice:

- group 1: normal mice treated with saline-1\% Tween 80 by gavage.

- group 2: diabetic mice treated with saline-1\% Tween 80 by gavage.

- group 3: diabetic mice treated with $50 \mathrm{mg} / \mathrm{kg}$ pioglitazone by gavage.

- group 4: diabetic mice treated with $12.5 \mathrm{mg} / \mathrm{kg}$ DMDD by gavage.

- group 5: diabetic mice treated with $25 \mathrm{mg} / \mathrm{kg}$ DMDD by gavage.

- group 6: diabetic mice treated with $50 \mathrm{mg} / \mathrm{kg}$ DMDD by gavage.

Administration of pioglitazone and DMDD was done daily at the same time up to 15 days.

\section{Determination of fasting blood glucose (FBG)}

All mice were fasted overnight. Levels of whole blood glucose were measured from the tail vein using an automatic glucometer, Accu-check Performa (Roche, Germany), on the initial, $7^{\text {th }}$ and $15^{\text {th }}$ day.

\section{Determination of serum fasting insulin (FINS), IL-6, TNF- $\alpha$ and lipids}

After 15 days, mice were fasted overnight. Blood samples were collected from the eyes and immediately centrifuged at $3500 \mathrm{rpm} / \mathrm{min}$ for $10 \mathrm{~min}$ at $4^{\circ} \mathrm{C}$ to obtain serum which was then refrigerated at $-70^{\circ} \mathrm{C}$ for determination of total cholesterol (TC), triglyceride (TG) and free fatty acid (FFA) levels using commercially available kits (Jiancheng Bioengineering Institute, Nanjing, China). By using the same serum, determination of FINS, IL- 6 and TNF- $\alpha$ levels was done by Cusabio mouse ELISA kits (Huamei Biotech Co., Ltd., Hubei, China).

\section{Collection of tissues}

After the blood samples were gathered, mice were sacrificed by cervical dislocation. An abdominal incision was performed to harvest pan-

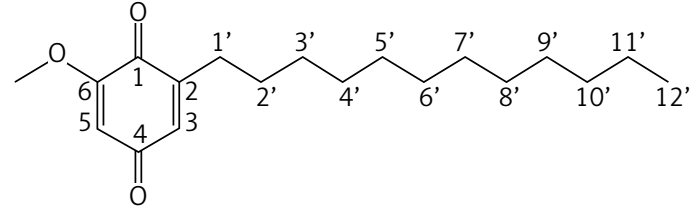

Figure 1. 2-dodecyl-6-methoxycyclohexa-2,5-diene1,4-dione

creas and adipose tissue. The whole organs were cleaned with chilled normal saline on ice.

\section{Determination of pancreatic insulin content}

The pancreas biopsy was weighed before being placed into $6 \mathrm{ml}$ of acidified ethanol (75\% ethanol, $1.5 \% 12 \mathrm{~mol} / \mathrm{l} \mathrm{HCl}$, and $23.5 \% \mathrm{H}_{2} \mathrm{O}$ ) and homogenized. The pancreas was incubated for $72 \mathrm{~h}$ at $4^{\circ} \mathrm{C}$ before being centrifuged $\left(20,000 \times g, 4^{\circ} \mathrm{C}\right)$ and the insulin content of the supernatant was determined using a commercial mouse insulin ELISA kit (Cusabio, Wuhan, China). Pancreatic insulin content was expressed as micrograms of insulin per gram of pancreas tissue.

\section{Histology of pancreas and adipose tissue}

The pancreas and adipose tissue (epididymal fat) specimens were fixed in $4 \%$ formalin solution and embedded in paraffin. Sections were cut at $4 \mu \mathrm{m}$ thickness with a microtome and deparaffinized with xylene. The sections were stained with haematoxylin-eosin (H\&E) staining. Stained sections were observed under a light microscope (Olympus CX4, Japan).

\section{Immunohistochemistry of adipose tissue}

$4 \mu \mathrm{m}$ epididymal fat sections were obtained from paraffin-embedded tissues. Under deparaffinization, $0.3 \%(\mathrm{v} / \mathrm{v})$ hydrogen peroxide was used to suppress endogenous peroxidase activity. The sections underwent a blocking step for 20 min with 5\% normal goat serum diluted in PBS. Endogenous biotin and avidin binding sites were blocked by avidin and biotin, respectively. Sections were incubated with rabbit anti-mouse polyclonal PPAR- $\gamma(1: 100)$ antibody (Santa Cruz Biotechnology, Inc. Texas, USA) in a moisture chamber and then treated with 3 '-diaminobenzidine (DAB) $0.01 \%$ hydrogen peroxide (Sigma, St. Louis, MO USA). Sections were counterstained with haematoxylin. Photographs at a magnification of $200 x$ were analysed by applying a light microscope (Olympus, CX4 Japan).

\section{Measurement of protein expression of PPAR- $\gamma$ by Western blot}

Epididymal fat samples were ground in liquid nitrogen. The total epididymal fat protein was 
isolated using a western blot lysis kit (Dingguo Biotechnology, China) and separated by $10 \%$ SDS-polyacrylamide gel electrophoresis (PAGE). Then, the proteins were transferred onto a nitrocellulose membrane and blocked with $5 \%$ dried milk for $1 \mathrm{~h}$. The primary antibody (1: 1000 antiPPAR- $\gamma$ ) (Abcam, USA) diluted in TBST containing $5 \%$ skim milk was added to the membrane and incubated at $4{ }^{\circ} \mathrm{C}$ overnight. After three washes with TBST, the secondary antibody conjugated to horseradish peroxidase (1:5000) (Abcam, USA) was added to the membrane and incubated for $1 \mathrm{~h}$. Immunoblots were developed on films using the enhanced chemiluminescence technique (Super Signal West Pico; Pierce Biotechnology, Rockford, IL). The densitometric analysis of the bands was determined with a UV light box (Gel Doc XR+, China). Following a stripping procedure the membranes were probed as above with a monoclonal anti- $\beta$-actin antibody (1: 1000). The data were normalized using $\beta$-actin as an internal control and standardized, with the vehicle control set to 1.0 .

\section{Measurement of PPAR- $\gamma$ mRNA expression by real rime polymerase chain reaction (RT-PCR)}

Total RNA was isolated from the epididymal fat pad of normal control, diabetic control and DMDD-treated diabetic mice using RNAiso Plus (Takara, Japan). An aliquot of $5 \mu \mathrm{g}$ of total RNA from each sample was reverse-transcribed to cDNA using the First-Strand cDNA Synthesis kit (Thermo Scientific, Massachusetts, USA). PCR amplification of $1 \mu \mathrm{l}$ of CDNA was carried out in a final volume of $50 \mu \mathrm{l}$ with the GeneAmp PCR System (Applied Biosystems, California, USA). PCR oligonucleotide sequences used are as follows:

Mouse PPAR- $\gamma$ primers creating a $153 \mathrm{bp}$ amplicon (Invitrogen, California, USA): sense primer (forward): 5'-GGAGCCTAAGTTTGAGTTTGCTGTG-3', anti-sense primer (reverse): 5'-TGCAGCAGGTTGTCTTGGATG-3'.

Mouse $\beta$-actin primers creating a 200 bp amplicon (Invitrogen, California, USA): sense primer (forward): 5'-GAGCTATGAGCTGCCTGACG-3', anti-sense primer (reverse): 5'-AGTTTCATGGATGCCACAGGA-3'.

Cycling conditions were as follows: $94^{\circ} \mathrm{C}$ for $30 \mathrm{~s}, 50-68^{\circ} \mathrm{C}$ for $30 \mathrm{~s}$, and $72^{\circ} \mathrm{C}$ for $60 \mathrm{~s}$, for $35 \mathrm{cy}-$ cles after an initial step of $95^{\circ} \mathrm{C}$ for $15 \mathrm{~min}$. A final elongation step of $72^{\circ} \mathrm{C}$ for 10 min completed the $P C R$. The PCR samples were electrophoresed on $2 \%$ agarose gels at $100 \mathrm{~V}$ and stained with SYBR green and photographed on a $280 \mathrm{~nm}$ UV light box (Gel Doc XR+, China).

\section{Statistical analysis}

Statistical analysis was performed using the SPSS software package (version 16.0). Results are expressed as the means \pm SEM $(N=10)$. Within-group comparisons were performed using the one-way ANOVA method. A value of $p<0.05$ was considered statistically significant.

\section{Results}

\section{Effect of DMDD on FBG and FINS}

In the present study, DMDD was isolated from roots of Averrhoa carambola L. We evaluated the effect of administration of DMDD on activity of hypoglycaemia in diabetic mice induced by STZ. Table I shows that the levels of FBG significantly decreased after administration of DMDD, compared with untreated diabetic mice. Prolonged DMDD administration was in line with its hypoglycaemic activity. In addition, FINS serum levels were also increased significantly in DMDD-treated diabetic mice, when compared to untreated diabetic mice. Diabetic mice treated with pioglitazone also showed improvement of FBG and FINS levels.

Table I. Effect of DMDD on FBG and FINS levels of normal and STZ-induced diabetic mice groups after 15 days of treatment

\begin{tabular}{|c|c|c|c|c|}
\hline \multirow[t]{2}{*}{ Groups } & \multicolumn{3}{|c|}{ Blood glucose level [mM] } & \multirow[t]{2}{*}{ FINS [mIU/l] } \\
\hline & Initial & 7 days & 15 days & \\
\hline Normal & $6.8 \pm 0.2$ & $6.3 \pm 0.5$ & $6.3 \pm 0.3$ & $28.43 \pm 0.41$ \\
\hline Diabetic control & $24.4 \pm 0.8^{\mathrm{a}}$ & $26.7 \pm 1.2^{\mathrm{a}}$ & $28.9 \pm 0.4^{a}$ & $14.44 \pm 0.91^{a}$ \\
\hline Diabetic + 50 mg/kg Pio & $24.1 \pm 1.2$ & $21.1 \pm 0.8^{b}$ & $17.1 \pm 1.3^{b}$ & $23.30 \pm 0.57^{b}$ \\
\hline Diabetic + 12.5 mg/kg DMDD & $24.5 \pm 0.9$ & $22.1 \pm 0.8^{b}$ & $20.3 \pm 1.1^{b}$ & $35.56 \pm 1.31^{b}$ \\
\hline Diabetic + 25 mg/kg DMDD & $24.2 \pm 0.7$ & $23.1 \pm 1.0^{\mathrm{b}}$ & $19.4 \pm 0.7^{b}$ & $35.86 \pm 1.21^{\mathrm{b}}$ \\
\hline Diabetic + 50 mg/kg DMDD & $24.6 \pm 0.7$ & $22.0 \pm 0.7^{b}$ & $19.9 \pm 1.3^{b}$ & $38.25 \pm 3.03^{b}$ \\
\hline
\end{tabular}

All values are given as mean \pm SEM (10 mice in each group). ${ }^{a} P<0.01$ compared with normal control group, ${ }^{b} p<0.01$ compared with diabetic control group. 


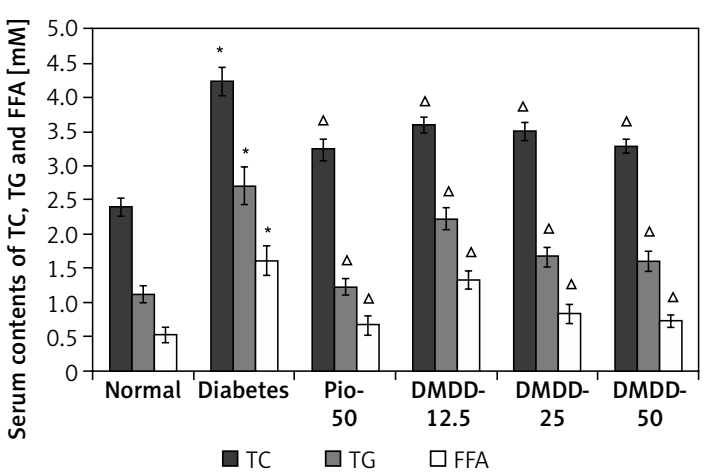

Figure 2. Effect of DMDD on lipid profiles. All values are given as mean \pm SEM (10 mice in each group)

${ }^{*} p<0.05$ compared with normal group; ${ }^{\Delta} p<0.05$ compared with diabetes group.

\section{Effect of DMDD on lipid profiles}

Hyperglycaemia is almost always accompanied by hyperlipidaemia. Thus, we also evaluated the effect of DMDD administration on hypolipidaemic activity in STZ-induced diabetic mice. After treatment with DMDD for 15 days, levels of TC, TG and FFA in serum of diabetic mice were significantly decreased, compared with untreated diabetic mice (Figure 2).

\section{Effect of DMDD on IL- 6 and TNF- $\alpha$}

IL- 6 and TNF- $\alpha$ adipocytokines secreted by adipose tissue have been confirmed to be adipocyte-derived factors that are correlated with an inflammatory response that leads to the development of diabetes. In our study, serum levels of IL- 6 and TNF- $\alpha$ were significantly increased in untreated diabetic mice, compared with normal mice. DMDD administration for 15 days signifi-

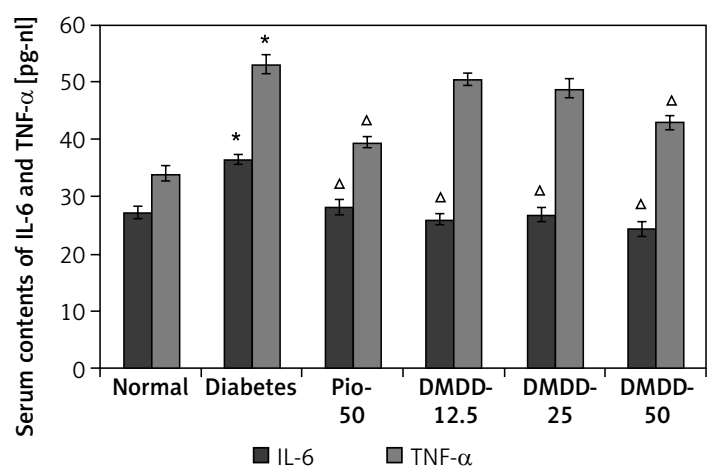

Figure 3. Effect of DMDD on serum contents of IL-6 and TNF- $\alpha$. All values are given as mean \pm SEM $(10$ mice in each group)

${ }^{*} p<0.05$ compared with normal group; ${ }^{\Delta} p<0.05$ compared with diabetic group.

cantly lowered the IL-6 level, and $50 \mathrm{mg} / \mathrm{kg}$ DMDD significantly lowered the TNF- $\alpha$ level (Figure 3).

\section{Effect of DMDD on pancreatic histology}

Islet cells of normal mice were compactly arranged, with negligible intercellular space, and no inflammatory cells were observed. Pancreatic islets in untreated diabetic mice (D) had obvious architectural disarray that also extended into the surrounding exocrine tissue. Islets isolated from mice treated with DMDD and pioglitazone also showed architectural disarray but to a lesser extent than untreated diabetic mice (Figure 4).

\section{Effect of DMDD on pancreatic insulin content}

The effect of DMDD on pancreatic insulin content in normal and streptozotocin (STZ)-induced diabetic mice is shown in Figure 5 . The pancreatic insulin content was significantly $(p<0.01)$
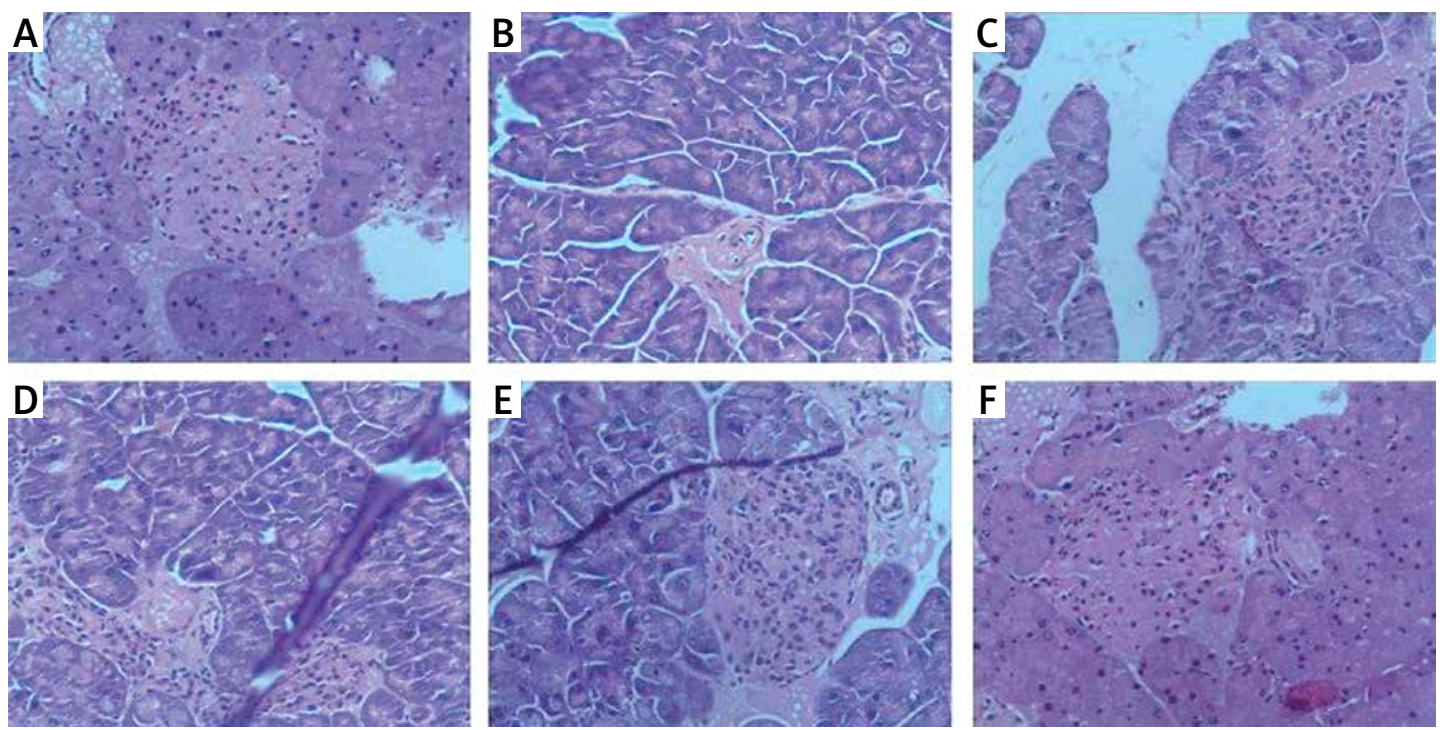

Figure 4. Histological observations of pancreas tissue. A - Normal mice, B - untreated diabetic mice, C - diabetic mice treated with $50 \mathrm{mg} / \mathrm{kg}$ pioglitazone, D - $12.5 \mathrm{mg} / \mathrm{kg}$ of DMDD, E - $25 \mathrm{mg} / \mathrm{kg}$ of DMDD, F - $50 \mathrm{mg} / \mathrm{kg}$ of DMDD 


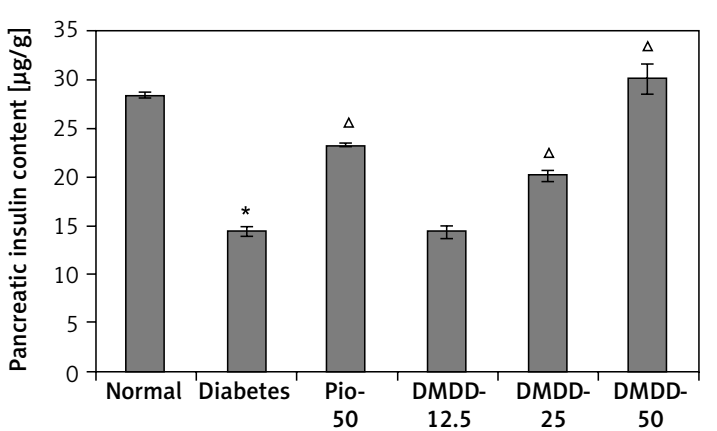

Figure 5. Effect of DMDD on insulin level in pancreas tissue. All values are given as mean \pm SEM (10 mice in each group)

${ }^{*} p<0.05$ compared with normal group; ${ }^{\Delta} p<0.05$ compared with diabetic group.

reduced in untreated diabetic mice as compared with normal mice. After treatment with pioglitazone and DMDD for 15 days, the pancreatic insulin content of diabetic mice was increased significantly $(p<0.01)$ when compared with untreated diabetic mice, especially at doses of 25 and $50 \mathrm{mg} /$ kg DMDD.

\section{Effect of DMDD on histology and immunohistochemistry of adipose tissue}

Increased levels of circulating serum lipids and excess lipid accumulation in non-adipose tissues are improved by PPAR- $\gamma$ ligands. In our investigation, we performed a study of the histology and immunohistochemistry of adipose tissue using epididymal fat. After treatment with pioglitazone or DMDD, histological examination of adipose tissue showed an increase in the number of small adipocytes compared with untreated diabetic mice. Further observation revealed macrophage infiltration in adipocytes (Figure 6). Immunohistochemical staining of adipose tissue revealed that the number and intensity of PPAR- $\gamma$-positive adipocytes were evidently increased in diabetic mice treated with DMDD and pioglitazone (Figure 7).

\section{Effect of DMDD on protein and mRNA expression of PPAR- $\gamma$}

The PPAR- $\gamma$ protein level in epididymal fat was examined using western blot analysis, as shown in Figure 8. The protein levels of PPAR- $\gamma$ were significantly $(p<0.05)$ lowered by $19.47 \%$ in untreated diabetic mice compared with normal mice. Pioglitazone administration significantly $(p<0.01)$ increased PPAR- $\gamma$ protein expression by $28.41 \%$ compared with untreated diabetic mice. DMDD administration at doses of $12.5,25$ and $50 \mathrm{mg} /$ $\mathrm{kg}$ significantly $(p<0.01)$ increased PPAR- $\gamma$ protein expression by $25.73 \%, 32.86 \%$ and $59.75 \%$, respectively.
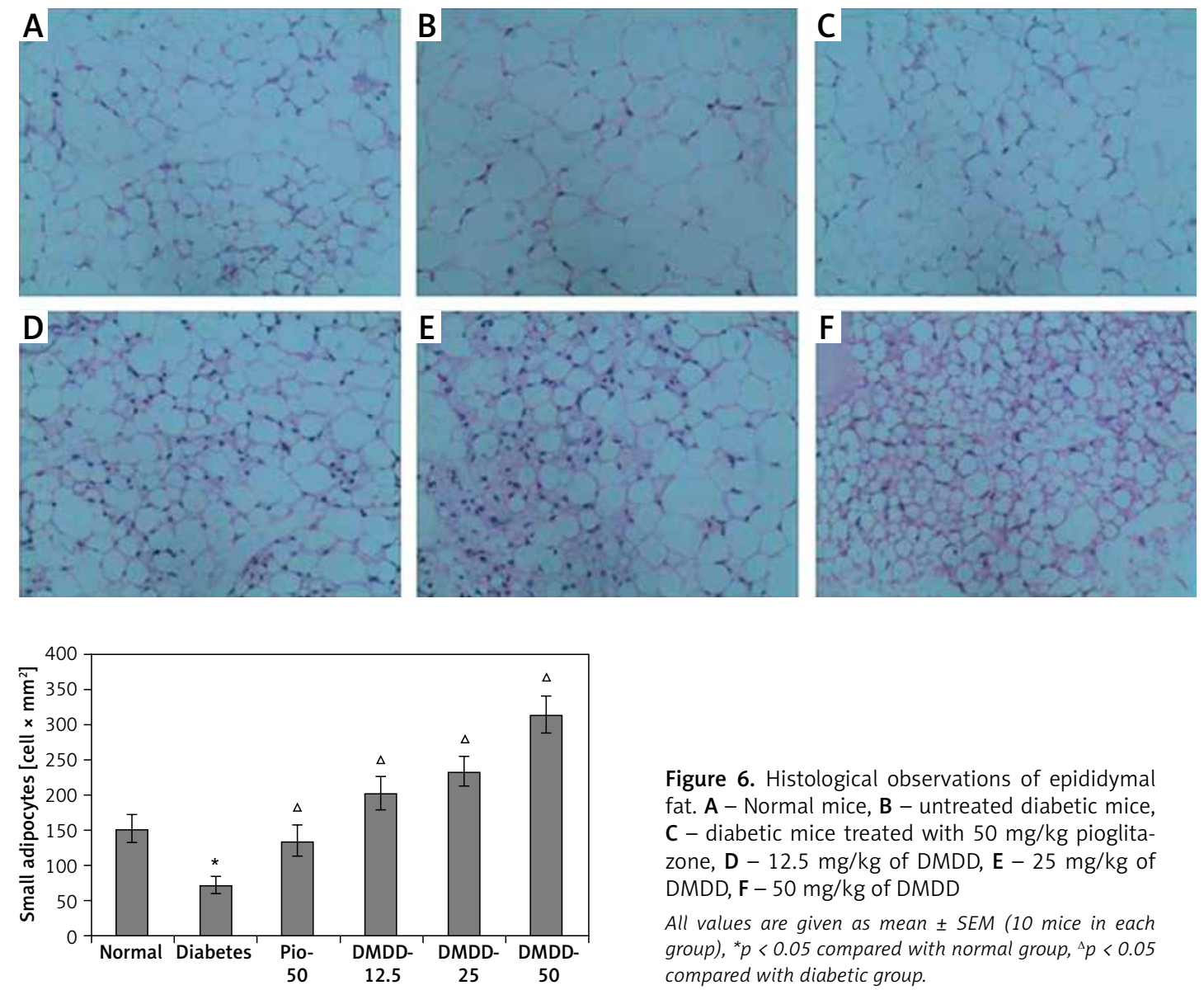

Figure 6. Histological observations of epididymal fat. A - Normal mice, B - untreated diabetic mice, C - diabetic mice treated with $50 \mathrm{mg} / \mathrm{kg}$ pioglitazone, $\mathbf{D}-12.5 \mathrm{mg} / \mathrm{kg}$ of DMDD, E - $25 \mathrm{mg} / \mathrm{kg}$ of DMDD, $\mathbf{F}-50 \mathrm{mg} / \mathrm{kg}$ of DMDD

All values are given as mean \pm SEM (10 mice in each group), ${ }^{*} p<0.05$ compared with normal group, ${ }^{\Delta} p<0.05$ compared with diabetic group. 

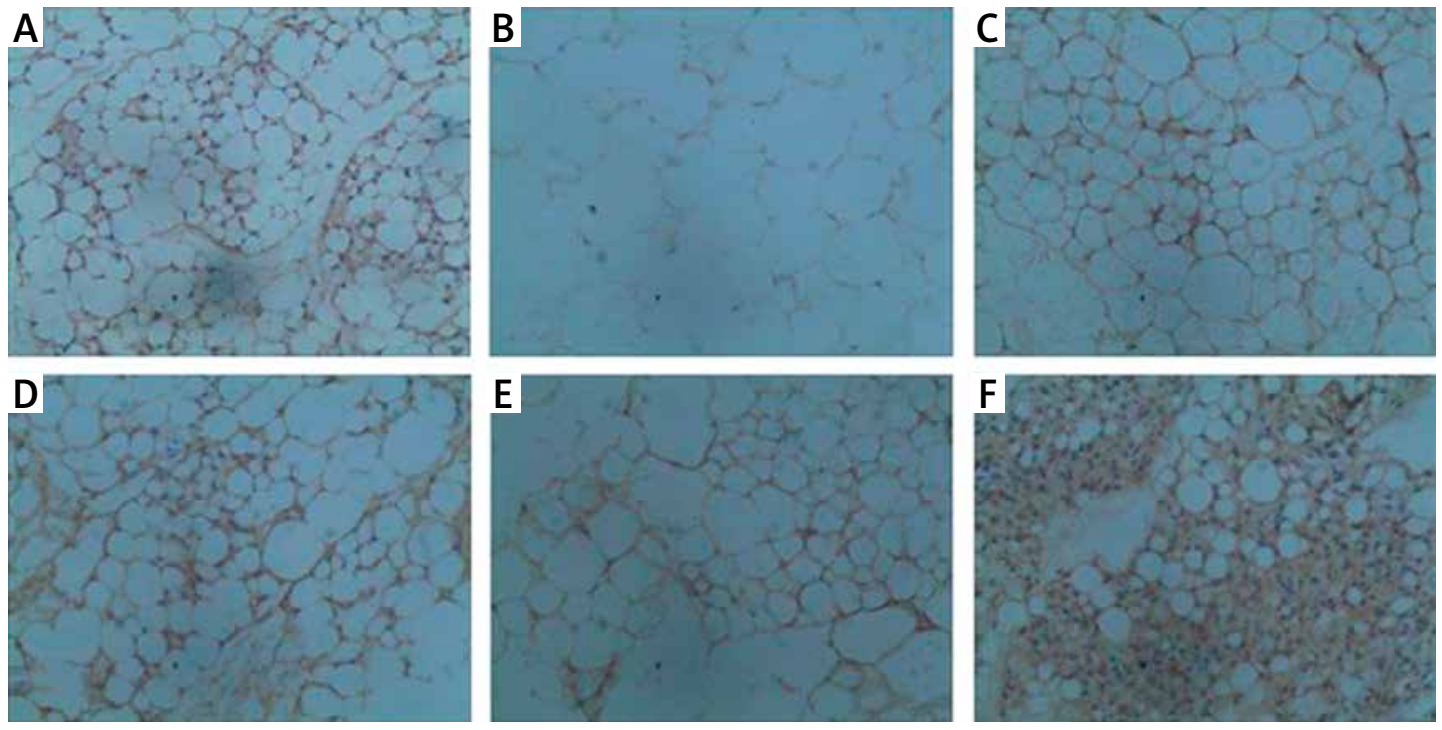

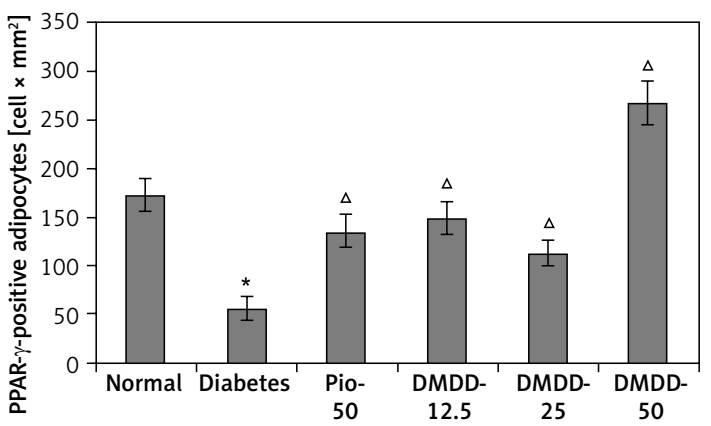

Figure 9 shows the effect of DMDD on PPAR- $\gamma$ mRNA expression in epididymal fat of diabetic mice. The level of PPAR- $\gamma$ mRNA was significantly lower in diabetic mice than in normal mice. DMDD treatment increased mRNA expression of PPAR- $\gamma$ significantly $(p<0.01)$ compared with untreated diabetic mice.
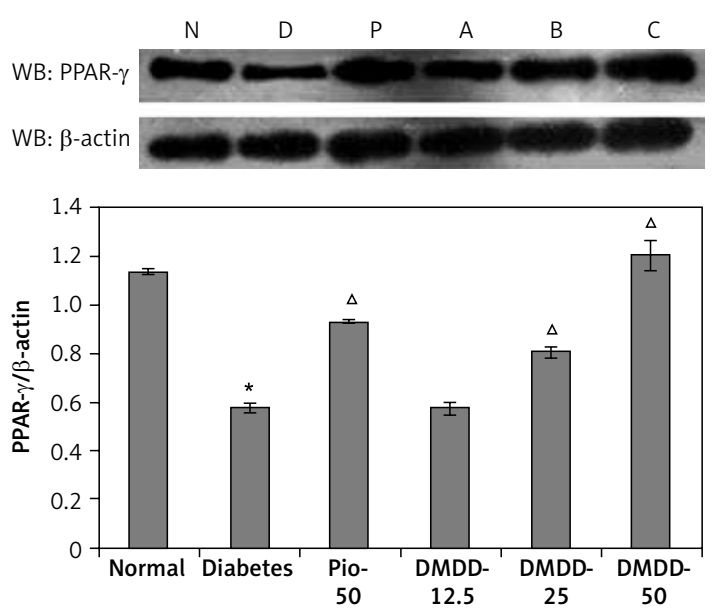

Figure 8. Effect of DMDD on expression of PPAR- $\gamma$ protein

All values are given as mean \pm SEM (10 mice in each group), * $p<0.05$ compared with normal group, ${ }^{\Delta} p<0.05$ compared with diabetic group.
Figure 7. Effect of DMDD on immunohistochemistry of epididymal fat. A - Normal mice, B - untreated diabetic mice, $\mathbf{C}$ - diabetic mice treated with $50 \mathrm{mg} / \mathrm{kg}$ pioglitazone, $\mathbf{D}-12.5 \mathrm{mg} / \mathrm{kg}$ of DMDD, $\mathrm{E}-25 \mathrm{mg} / \mathrm{kg}$ of DMDD, $\mathbf{F}-50 \mathrm{mg} / \mathrm{kg}$ of DMDD

All values are given as mean \pm SEM (10 mice in each group), ${ }^{*} p<0.05$ compared with normal group, ${ }^{\Delta} p<0.05$ compared with diabetic group.

\section{Discussion}

Diabetes mellitus is characterized by hyperglycaemia resulting from defects in insulin secretion, insulin action or both [1]. The current treatment of diabetes targets the two main pathogenic defects of the disease, namely $\beta$-cell dysfunction and
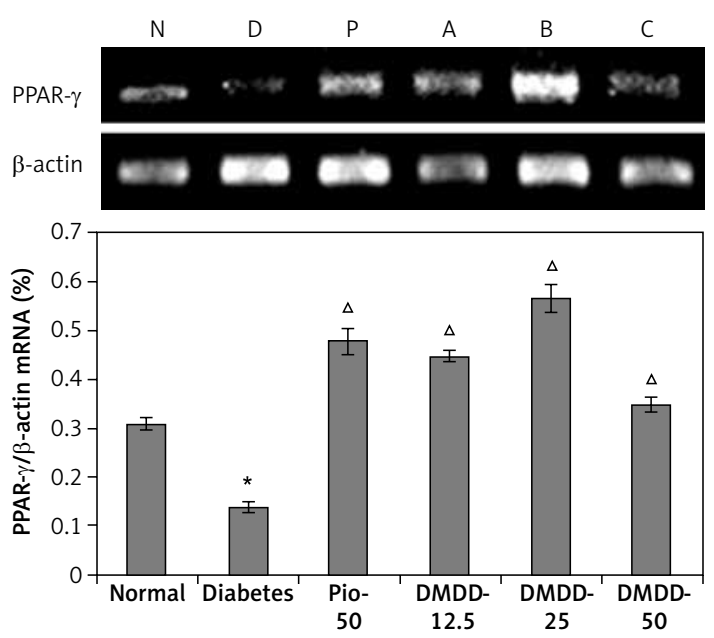

Figure 9. Effect of DMDD on expression of PPAR- $\gamma$ mRNA

All values are given as mean \pm SEM (10 mice in each group), ${ }^{*} p<0.05$ compared with normal group, ${ }^{\Delta} p<0.05$ compared with diabetic group. 
insulin resistance. DMDD isolated from Averrhoa carambola $\mathrm{L}$. roots is a 1,4-benzoquinone derivative [16]. Natural compounds and synthetic derivatives possessing a 1,4-benzoquinone moiety are associated with a range of biological properties [14], such as anti-diabetes [15, 22-24], anti-inflammatory [22], and anti-hyperlipidaemic activities [24].

Furthermore, several factors such as hyperglycaemia, hyperlipidaemia, inflammation and insulin resistance affect regeneration of pancreatic $\beta$-cells. Diminishing these factors leads to increased insulin secretion [25]. In fact, the progressive decline of $\beta$-cell function over time does not seem to be an irreversible process; some data suggest that treatment can temporarily improve $\beta$-cell function [26]. Gupta et al. reported that embelin, a 1,4-benzoquinone, protects pancreatic $\beta$-cells, leading to increasing insulin secretion [15]. These findings are in line with our present study showing that DMDD possessed hypoglycaemic activity. On the other hand, levels of the serum adipocytokines IL- 6 and TNF- $\alpha$ were significantly decreased after administration of DMDD. The FINS serum levels in DMDD-treated diabetic mice were also significantly increased, as well as the insulin secretion indexes of DMDD-treated mice. Thus, DMDD might induce secretion of insulin and improvement of $\beta$-cell damage through its ability to alleviate blood glucose and the inflammatory response. Meanwhile, DMDD showed a higher increase of pancreatic insulin content $(30.1 \mathrm{\mu g} / \mathrm{g})$ than that observed for pioglitazone $(23.3 \mu \mathrm{g} / \mathrm{g})$. The secretion of insulin could be associated with the increased pancreatic insulin content. The insulin levels in DMDD groups were even above normal levels. We thought that DMDD could enhance the insulin sensitivity of diabetic mice, but insulin resistance still exists. Histologically, both acinar and islet components of pancreas in DMDD-treated diabetic mice are structurally similar to each other, suggesting that the islet is returning to its normal structure. This phenomenon was most obvious at $50 \mathrm{mg} / \mathrm{kg}$ DMDD. Additionally, this finding is strengthened by previous studies that describe an increase in the mitotic index of $\beta$-cells in injured pancreata, and show that $\beta$-cell regeneration can result from the proliferation of pre-existing $\beta$-cells [27].

In addition, abnormalities in lipid metabolism are associated with insulin resistance [25]. We observed that TC, TG and FFA of untreated diabetic mice were significantly increased. DMDD administration improved hyperlipidaemia in serum. In comparison to DMDD, pioglitazone was more effective at lowering TG than TC. This result is strengthened by a clinical study showing that after treatment with pioglitazone, patients had significant reductions in triglycerides $(-15.2 \%)$ and total cholesterol (-9.0\%) [28]. Decreases in very-low-density lipoprotein levels were in line with reduced TG levels [29-31].

Many studies have reported that lipid homeostasis is controlled by PPAR- $\gamma$ ligands [19]. Adipocytokines IL- 6 , TNF- $\alpha$ and PPAR- $\gamma$ are closely related to type 2 diabetes and its complications. By reducing IL- 6 and TNF- $\alpha$ levels, the inflammatory response will also be lowered. In addition, increased PPAR- $\gamma$ expression was associated with insulin sensitivity, leading to $\beta$-cell preservation [20]. PPAR- $\gamma$ expression is dramatically higher in fat than in liver, and in particular muscle [6]. In addition, pioglitazone, a thiazolidinedione, is a PPAR- $\gamma$ agonist, and the anti-diabetic mechanism is associated with enhancing the insulin sensitivity of adipose tissue. Hence, epididymal fats were used in our study to further investigate the role of PPAR- $\gamma$ in hypoglycaemia. The immunohistochemical study revealed that PPAR- $\gamma$ was highly expressed in epididymal fat of diabetic mice treated with DMDD and pioglitazone. Interestingly, the number of PPAR- $\gamma$-positive adipocytes in the $50 \mathrm{mg} / \mathrm{kg}$ DMDD group was much higher than that in the pioglitazone group. DMDD showed a better activation effect than pioglitazone and PPAR- $\gamma$ agonists. Furthermore, the number and intensity of PPAR- $\gamma$-positive adipocytes were greater than in untreated diabetic mice. Moreover, rodent and human studies have shown that adipose enlargement was associated with decreased insulin responsiveness [32].

Histological examination of epididymal fat revealed that DMDD and pioglitazone increased the number of small adipocytes. This may be due to their stimulatory effect on PPAR- $\gamma$-mediated adipocyte differentiation. Previous studies have supported that activation of PPAR- $\gamma$ in 3T3-L1 preadipocytes was associated with differentiation of preadipocytes into mature adipocytes [33]. The stimulation of adipocyte differentiation results in an increased population of small adipocytes, which are more insulin sensitive. The increase in the number of small adipocytes may also account for the reduction in hypertriglyceride, since smaller fat cells are known to be more sensitive to the antilipolytic action of insulin [34]. Thus, DMDD might play a key role in white adipocyte differentiation.

The possible mechanism by which DMDD increases the number of small size adipocytes might be by stimulating expression of differentiation markers such as C/EBP $\alpha$ and A2COL6, and concomitantly stimulating expression of genes involved in maturation of adipocytes, such as PEPCK and FAS, to increase the capacity of fat storage. This notion is supported by Martin et al., who reported that activated PPAR- $\gamma$ can stimulate the expression of adipocyte-specific genes involved in 
adipocyte differentiation, such as C/EBP $\alpha$ [35]. In fact, genes involved in lipid uptake and storage, such as PEPCK, lead to increase uptake of FFA to be stored in adipocytes and reduce release of FFA into the circulation. This is in line with our finding showing that administration of DMDD reduced serum levels of FFA in diabetic mice. The results demonstrated that DMDD may exert a hypoglycaemic effect through regulating the expression of PPAR- $\gamma$, which mediates the endocrine function of adipocytes and reduces lipid profiles.

In conclusion, however, in our present study we found adipose tissue infiltrated by macrophage cells. This finding might be explained by the appearance of newly differentiated adipocytes within a few weeks after the death of PPAR- $\gamma$-ablated adipocytes. Stienstra et al. reported that activation of PPAR- $\gamma$ promotes macrophage infiltration into adipose tissue, supporting this hypothesis [36]. However, PPAR- $\gamma$ simultaneously reduces inflammatory gene expression, as evidenced by reductions in serum IL- 6 and TNF- $\alpha$ levels in DMDD-treated diabetic mice, which were observed in the present study. In summary, DMDD possessed hypoglycaemic activity though a mechanism involving PPAR- $\gamma$-mediated adipocyte endocrine regulation and insulin secretion.

\section{Acknowledgments}

This research was supported by the National Natural Science Foundation of China (No. 81160533, 81360129); Guangxi Natural Science Foundation (No. 2012GXNSFAA053106, No. 0832013Z); Guangxi Key Laboratory for Metabolic Disease Research (No. 2012-181h-02); Nanning Science and Technology Research and Production of New Products (No. 201102084C); Education Innovation Plan Program for Postgraduate in Guangxi (No. 2011105981002D27); and Innovation Project of Guangxi Graduate Education (YCBZ2015035).

Kintoko Kintoko and Xiaohui Xu contribute equally to this work.

\section{Conflict of interest}

The authors declare no conflict of interest.

\section{References}

1. American Diabetes Association. Diagnosis and classification of diabetes mellitus. Diabetes Care 2006; 29 (suppl 1): S43-8.

2. Zimmet $P$. The burden of type 2 diabetes: are we doing enough? Diabetes Metab 2003; 29: 659-18.

3. International Diabetes Federation. Type 1 diabetes: a very special issue. Diabetes Voice 2011; 56: 4-49.

4. Sun K, Li F, Qi Y, et al. Sex difference in the association between habitual daytime napping and prevalence of diabetes: a population-based study. Endocrine 2016; 52: $263-70$.
5. Wong KC, Wang Z. Prevalence of type 2 diabetes mellitus of Chinese populations in mainland China, Hongkong, and Taiwan. Diabetes Res Clin Pract 2006; 73: 126-34.

6. Dembitsky VM, Poovarodom S, Leontowicz $\mathrm{H}$, et al. The mutiple nutrition properties of some exotic fruits: biological activity and active metabolites. Food Res Int 2011; 44: 1671-701.

7. Gunasekara LCA, Fernando PHP, Sivakanesan R. A preliminary study on the hypoglycaemic effect of Averrhoacarambola (star fruit) in rats. Proceedings of the Peradeniya University Research Sessions, Sri Lanka 2011.

8. Chau CF, Chen CH, Lee MH. Characterization and physiochemical properties of some potential fibers derived from Averrhoacarambola. Nahrung 2004; 48: 43-6.

9. Ferreira EB, Fernandes LC, Galende SB, Cortez DAG, Bazotte RB. Hypoglycemic effect of the hydroalcoholic extract of leaves of Averrhoacarambola L. (Oxalidaceae). Brazilian J Pharmacog 2008; 18: 339-43.

10. Cazarolli LH, Kappel VD, Pereira DF, et al. Anti-hyperglycaemic action of apigenin-6-C-beta-fucopyranoside from Averrhoacarambola. Fitoterapia 2012; 83: 1176-83.

11. Cazarolli LH, Folador P, Moresco HH, Brighente IM, Pizzolatti MG, Silva FR. Mechanism of action of the stimulatory effect of apigenin-6-C-beta-fucopyranoside on 14C-glucose uptake. Chem Biol Interact 2009; 179: 407-12.

12. Zheng N, Lin X, Wen Q, et al. Effect of 2-dodecyl-6-methoxycyclohexa-2,5-diene-1,4-dione, isolated from Averrhoacarambola L. (Oxalidaceae) roots, on advanced glycation end-product-mediated renal injury in type 2 diabetic KKAy mice. Toxicol Lett 2013; 29: 77-84.

13. Ivorra MD, Paya M, Villar A. A review of natural products and plants as potential antidiabetic drugs. J Ethnopharmacol 1989; 27: 243-75.

14. Dandawate PR, Vyas AC, Padhye SB, Singh MW, Baruah JB. Perspectives on medicinal properties of benzoquinone compounds. Mini Rev Med Chem 2010; 10: 436-54.

15. Gupta R, Sharma AK, Sharma MS, Gupta RS. Antioxidant activity and protection of pancreatic beta-cells by embelin in streptozotocin-induced diabetes. J Diabetes 2012; 4: 248-56.

16. Wen Q, Lin X, Liu Y, et al. Phenolic and lignan glycosides from the butanol extract of Averrhoa carambola L. root. Molecules 2012; 17: 12330-40.

17. Ginsberg HN, Zhang YL, Hernandez-Ono A. Regulation of plasma triglyceride in insulin resistance and diabetes. Arch Med Res 2005; 36: 232-40.

18. van den Oever IA, Raterman HG, Nurmohamed MT, Simsek S. Endothelial dysfunction, inflammation, and apoptosis in diabetes mellitus. Mediators Inflamm 2010; 2010: 792393.

19. Rangwala SM, Lazar MA. Peroxisome proliferator-activated receptor in diabetes and metabolism. Trends Pharmacol Sci 2004; 25: 331-6.

20. Higa M, Zhou, YT, Ravazzola M, Baetens D, Orci L, Unger RH. Troglitazone prevents mitochondrial alterations, beta cell destruction, and diabetes in obese prediabetic rats. Proc Natl Acad Sci USA 1996; 96: 11513-8.

21. Xu X, Liang T, Lin X, et al. Effect of the total extract of Averrhoacarambola (Oxalidaceae) root on the expression levels of TLR4 and NF-kappaB in streptozotocin-induced diabetic mice. Cell Physiol Biochem 2015; 36: 2307-16.

22. Naik SR, Niteru NT, Ansari AA, Shah PD. Anti-diabetic activity of embelin: involevement of cellular inflammatory 
mediators, oxidative stress and other biomarkers. Phytomedicine 2013; 20: 797-804.

23. Bhandari U, Jain N, Ansari MN, Pillai KK. Beneficial effect of Embeliaribesethanolic extract on blood ressure and glycosylated haemoglobin in streptozotocin-induced diabetes in rats. Fitoterapia 2008; 79: 351-5.

24. Mahendran S, Badami S, Maithili V. Evaluation of antidiabetic effect of embelin from Embelia ribes in alloxan induced diabetes in rats. Biomed Prevent Nutr 2011; 1: 25-31.

25. Marchetti P, Dotta F, Lauro D, Purrello F. An overview of pancreatic beta-cell defects in human type 2 diabetes: implication for treatment. Regular Pept 2008; 146: 4-11.

26. United Kingdom Prospective Diabetes Study Group 16. Overview of 6 years' therapy of type 2 diabetes: a progressive disease. Diabetes 1995; 44: 1249e58.

27. Desgraz R, Bonal C, Herrera PL. Beta-cell regeneration: the pancreatic intrinsic faculty. Trends Endocrin Metabol 2011; 22: 34-43.

28. Berhanu P, Kipnes MS, Khan MA, et al. Effects of pioglitazone on lipid and lipoprotein profiles in patients with type 2 diabetes and dyslipidaemia after treatment conversion from rosiglitazone while continuing stable statin therapy. Diabet Vascul Dis Res 2006; 3: 39-44.

29. Lewis GF. Fatty acid regulation of very low density lipoprotein (VLDL) production. Curr Opin Lipidol 1999; 10: 475-7.

30. Katsiki N, Nikolic D, Montalto G, Banach M, Mikhailidis DP, Rizzo M. The role of fibrate treatment in dyslipidemia: an overview. Curr Pharm Des 2013; 19: 3124-31.

31. Banach M, Aronow WS, Serban MC, Rysz J, Voroneanu L, Covic A. Lipids, blood pressure and kidney update 2015. Lipids Health Dis 2015; 14: 167.

32. Liu A, Sonmez A, Yee G, et al. Differential adipogenic and inflammatory properties of small adipocytes in Zucker obese and lean rats. Diabet Vascul Dis Res 2010; 7 : 311-8.

33. Ohsumi J, Sakakibara S, Yamaguchi J, et al. Troglitazone prevents the inhibitory effects of inflammatory cytokines on insulin-induced adipocyte differentiation in 3T3-L1 cells. Endocrinology 1994; 135: 2279-82.

34. Abbott WG, Foley JE. Comparison of body composition, adipocyte size and glucose and insulin concentration in Pima Indian and Caucasian children. Metabolism 1978; 36: 576-9.

35. Martin G, Schoonjans K, Staels B, Auwerx J. PPARgamma activators improve glucose homeostasis by stimulating fatty acid uptake in the adipocytes. Atherosclerosis 1998; 137: S75-80.

36. Stienstra R, Duval C, Keshtkar S, van der Laak J, Kersten S, Muller M. Peroxisome proliferator-activated receptor gamma activation promotes infiltration of alternatively activated macrophages into adipose tissue. J Biol Chem 2008; 283: 2620-7. 